\title{
Synthesis of 10-methyl-8,10-diazabicyclo[4.3.1]decane as a new building block for nicotinic modulators
}

\author{
Osvaldas Paliulis, ${ }^{\text {a Dan Peters, }}{ }^{\mathrm{b}}$ Wolfgang Holzer ${ }^{\mathrm{c}}$ and Algirdas Šačkus ${ }^{\mathrm{a} *}$ \\ ${ }^{a}$ Kaunas University of Technology, Institute of Synthetic Chemistry, Radvilenu pl. 19, Kaunas, \\ LT-50254, Lithuania \\ ${ }^{b}$ DanPET AB, Rosenstigen 7, Malmö, 216 19, Sweden \\ ${ }^{c}$ Department of Drug and Natural Product Synthesis, Faculty of Life Sciences, University of \\ Vienna, Althanstrasse 14, Vienna, A-1090, Austria \\ E-mail: algirdas.sackus@ktu.lt
}

\begin{abstract}
A convenient method for the synthesis of 10-methyl-8,10-diazabicyclo[4.3.1]decane, possessing a novel diazabicyclic ring system, as an important synthetic organic chemistry building block was developed using octanedioic acid as a starting material. The key transformation in the 5-step synthesis sequence involved a reaction of dimethyl 2,7-dibromooctanoate with methylamine, which resulted in the formation of cis-dimethyl 1-methylazepan-2,7-dicarboxylate. The latter was further transformed into bicyclic 8-benzyl-10-methyl-8,10-diazabicyclo[4.3.1]decane-7,9dione under heating with benzylamine. Reduction of the formed bicyclic dione with lithium aluminium hydride resulted in 8-benzyl-10-methyl-8,10-diazabicyclo[4.3.1]decane, and hydrogenolysis efficiently yielded the target product.
\end{abstract}

Keywords: Octanedioic acid, meso-dimethyl 2,7-dibromooctanedioate, azepane, 8,10diazabicyclo[4.3.1]decane

\section{Introduction}

Diazabicycloalkanes are important synthetic precursors in the preparation of compounds with a variety of biomedical applications. For example, derivatives of 3,8-diazabicyclo[3.2.1]octane and 1,4-diazabicyclo[3.2.2]nonane were used as the starting materials for the synthesis of various biologically active molecules, including $\alpha-7$ nicotinic acetylcholine receptor agonists, which can be used for the treatment of diseases or disorders related to the central nervous system (CNS) and peripheral nervous system (PNS). ${ }^{1-6}$ Adducts of 3,8-diazabicyclo[3.2.1] octane, 1,4diazabicyclo[3.2.2]nonane and other similar diazabicycles with quinolones resulted in products with significant antibacterial activity. ${ }^{7}$ 1,4-Diazabicyclo[3.2.2] nonanes also serve as precursors 
in the preparation of ${ }^{18} \mathrm{~F}$ isotope-containing potential radiotracers for imaging $\alpha-7$ nicotinic acetylcholine receptors, ${ }^{8,9}$ whereas 3,10-diazabicyclo[4.3.1]decane derivatives are used in the synthesis of ${ }^{11} \mathrm{C}$-labeled serotonin transporter ligands. ${ }^{10}$ Recently, it was shown that 10-methyl8,10-diazabicyclo[4.3.1]decane derivatives are potent nicotinic modulators and may be useful in the treatment of diseases related to the cholinergic system of the CNS or PNS. ${ }^{11}$ However, the synthetic route of 10-methyl-8,10-diazabicyclo[4.3.1]decane and the spectral and physical characteristics of this compound have not been previously determined. To fill this gap, the synthesis of 10-methyl-8,10-diazabicyclo[4.3.1]decane is presented in the current work.

Various synthetic methods have been described in the literature for diazabicycles, which vary depending on the size of the ring system, the position of the ring nitrogen atoms and the availability of starting materials. For example, 1,4-diazabicyclo[3.2.2]nonane was prepared from 3-quinuclidinone oxime employing the strong acid-catalysed Beckmann rearrangement. Heating of the obtained by a such way 1,4-diazabicyclo[3.2.2]nonan-3-one with lithium aluminium hydride produced the target bicyclic compound. ${ }^{12}$ The construction of 2,7diazabicyclo[3.1.1]nonanes was carried out starting from 2-(2-cyano-2-phenylethyl)aziridines via their transformation to 2-chloromethyl-4-phenylpiperidine-4-carbonitriles. ${ }^{13}$ The synthesis of 3,8-diazabicyclo[3.2.1]octane was performed by a multi-step procedure starting from dimethyl meso-2,5-dibromoadipate via its conversion to cis-dimethyl 1-benzylpyrrolidine-2,5dicarboxylate. Reaction of this intermediate compound with a second equivalent of benzylamine resulted in 3,8-dibenzyl-3,8-diazabicyclo[3.2.1] octan-2,4-dione, which was reduced and resulted in the final bicyclic product after hydrogenolysis. ${ }^{14,15}$ Similar synthesis strategies were employed for the preparation of 8-methyl- and 8-ethyl-3,8-diazabicyclo[3.2.1] octanes. ${ }^{16}$ Recently, a new method for the preparation of 3-benzyl-3,8-diazabicyclo[3.2.1] octane was proposed based on the reaction of benzylamine with mesylated 2,5-dihydroxymethylpyrrolidine, which is a product obtained from meso-2,5-dibromoadipate using a multi-step procedure. ${ }^{17}$

\section{Results and Discussion}

To synthesize the desired 10-methyl-8,10-diazabicyclo[4.3.1]decane, we have selected a strategy in which the main step included the synthesis of intermediate cis-azepane dicarboxylate starting from commercially available suberic (octanedioic) acid, which was followed by the transformation of this intermediate into bicyclic 8,10-diazabicyclo[4.3.1]decane (Scheme 1). A similar strategy has been successfully applied for the preparation of 8-alkyl-3,8diazabicyclo[3.2.1] octanes from adipic acid, ${ }^{15}$ as mentioned above. We initiated synthesis by preparing dimethyl 2,7-dibromooctanedioate (2) from suberic acid (1). It is known that bromination of suberic acid under Hell-Volhard reaction conditions results in racemic and meso2,7-dibromosuberic acids as a mixture of diastereomers. ${ }^{18}$ In 1981, Tokuda et al. described a protocol to afford dimethyl 2,7-dibromooctanedioate as a mixture of rac and meso isomers via bromination of octanedioyl dichloride with a mixture of phosphorus tribromide and dry bromine 
followed by treatment of the crude intermediate product with absolute methanol. ${ }^{19}$ However, it was shown by Blackman and Baltzly ${ }^{16}$ that the formation of the corresponding cyclic amines, which are in the required cis-configuration and can only serve as precursors of bicyclic derivatives, took part, when the starting dibrominated alkanedioate contains the mesoconfiguration, whereas the dibrominated rac-alkanedioate preferentially results in the transconfiguration product.

We started the preparation of dimethyl 2,7-dibromooctanedioate (2) by transformation of suberic acid (1) to octanedioyl dichloride (Scheme 1) via reaction with thionyl chloride as it was described in the aforementioned work. ${ }^{19}$ However, bromination of the obtained intermediate octanedioyl dichloride was carried out by us applying radical reaction pathway, when after addition of bromine the reaction flask was continuously irradiated with a $200 \mathrm{~W}$ mercury lamp. Treatment of the reaction mixture with methanol and distillation of the obtained product under high vacuum, resulted in the target dimethyl 2,7-dibromooctanedioate (2) in $84 \%$ isolated yield. The ${ }^{1} \mathrm{H}$ - and ${ }^{13} \mathrm{C}-\mathrm{NMR}$ spectra of 2 revealed one set of signals, which indicated the formation of one of the two possible diastereomers only, that is, the radical bromination proceeded diastereoselectively.

The second and crucial step of the synthesis was the formation of the azepane cycle by the reaction of dibromodiester (2) with methylamine. It is known that diethyl meso-2,5dibomoadipate underwent cyclisation to the corresponding 5-membered pyrrolidine derivative by reacting with methylamine at room temperature. ${ }^{15}$ When the reaction of dibromodiester (2) with methylamine was performed under similar reaction conditions, the desired cyclic product, dimethyl cis-1-methylazepan-2,7-dicarboxylate (4), was separated by column chromatography with a $6 \%$ yield only. However, when the reaction temperature was elevated to $120{ }^{\circ} \mathrm{C}$, a complex mixture of products was produced, from which the desired azepane $\mathbf{4}$ was obtained by yield of $28 \%$. Notably, analysis of the crude product (before vacuum distillation) using ${ }^{1} \mathrm{H}$ and ${ }^{13} \mathrm{C}$ NMR spectroscopy and liquid chromatography/mass-spectrometry revealed the presence in the mixture of the second diastereomer, dimethyl trans-1-methylazepan-2,7-dicarboxylate (the ratio of cis/trans products in a crude mixture was approximately 10/1 in the ${ }^{1} \mathrm{H}$ NMR spectrum). The stereochemical outcome of the reaction can be rationalised by the $\mathrm{S}_{\mathrm{N}} 2$-type nucleophilic displacement of one of the bromine atoms of meso-dimethyl 2,7-dibromooctanedioate 2 by the nitrogen atom of methyl amine, which resulted in a Walden inversion to form the intermediate $\mathbf{3}$. Compound 3 undergoes ring-closure by the substitution of the second bromine atom to provide the final product $\mathbf{4}$, which is in the cis-configuration. The presence in the crude reaction product of the corresponding trans-isomer as a side-product can be explained by a partial transformation of the starting meso-2 to rac-2 under the reaction conditions. ${ }^{16}$ It is important to note, that the use of milder reaction conditions or the application of aromatic solvents such as toluene or xylene instead THF, did not increase the yield of the target product 4.

Using liquid chromatography/mass-spectrometry it was established also that during the reaction of $\mathbf{2}$ with methylamine at elevated temperature, the ester groups of intermediate substrates underwent partially the reactions of aminolysis to yield the corresponding amides as 
side products, including methylamide 5a, with lowering the yield of the target product. More ever, the amide 5a can take part in the intramolecular cyclisation to form bicyclic 8,10-dimethyl8,10-diazabicyclo[4.3.1]decane-7,9-dione 6a. Indeed, heating of the reaction residue obtained after separation of $\mathbf{4}$ at $205^{\circ} \mathrm{C}$, afforded imide $\mathbf{6 a}$ with the isolated yield $10 \%$.
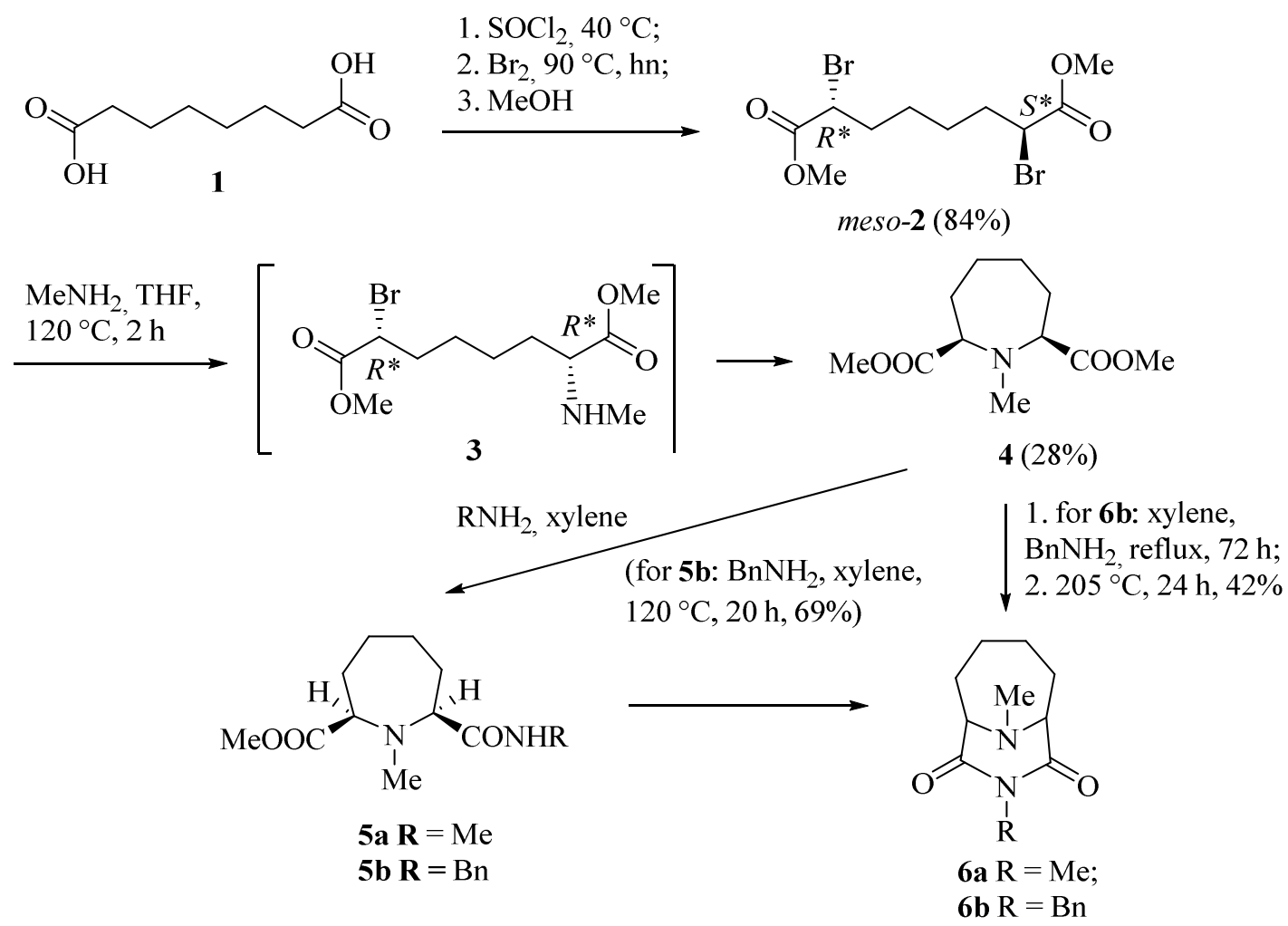

Scheme 1. Synthesis of 8,10-diazabicyclo[4.3.1]decan-7,9-diones.
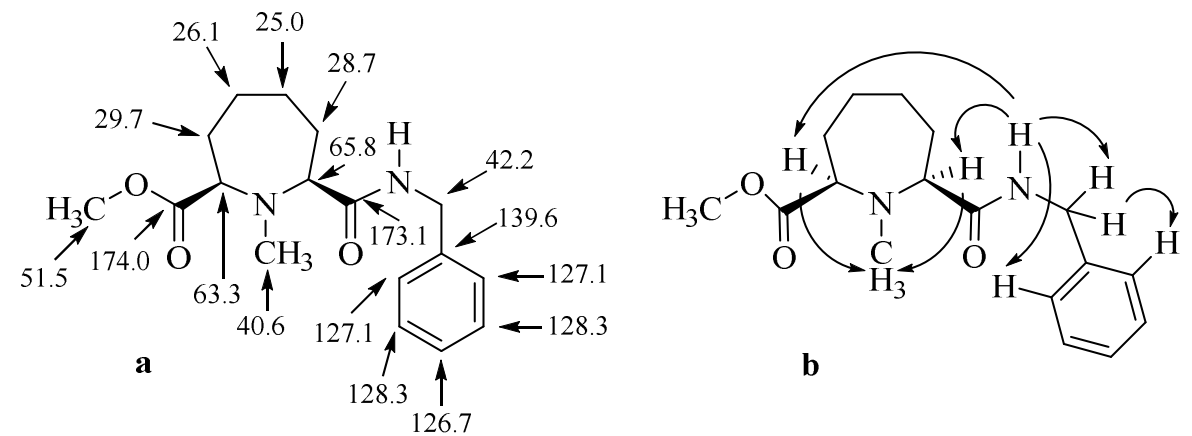

b

Figure 1. (a) ${ }^{13} \mathrm{C}$ chemical shifts of $\mathbf{5 b}$ (ppm; ref. TMS in DMSO- $d_{6}$ ). (b) Relevant NOE correlations. 
It is worth to point out that azepane ring is present in various natural medicinally important bioactive compounds, such as bengamides ${ }^{20-22}$ and balanols ${ }^{23,24}$ and their synthetic analogues, while azepane quaternary amino acids found application in the preparation of conformationally constrained peptidomimetics. $^{25,26}$

Furthermore, we investigated the aminolysis of diester 4 with benzylamine. To determine the optimum reaction conditions for increasing the yield, this reaction was studied under various conditions. Heating of diester 4 with benzylamine in xylene at $120{ }^{\circ} \mathrm{C}$ for $20 \mathrm{~h}$, afforded monoamide $\mathbf{5 b}$ as a main product in a $69 \%$ yield. The structure of $\mathbf{5 b}$ was confirmed by methods of NMR spectroscopy. The assignments presented in Fig. 1a, b were based on the combined application of standard NMR techniques such as NOESY, APT, HSQC and HMBC. ${ }^{27}$

When the aminolysis of diester 4 with benzylamine was performed at $160{ }^{\circ} \mathrm{C}$ (oil bath temperature) for $48 \mathrm{~h}$, it resulted in a mixture of monoamide $\mathbf{5} \mathbf{b}$, and the corresponding diamide, whereas only traces of bicyclic imide $\mathbf{6 b}$ were detected. Much better yield of $\mathbf{6 b}$ was obtained, when after heating at $160{ }^{\circ} \mathrm{C}$ for a prolonged time, the reaction mixture was placed under high vacuum to remove unreacted reagents, and the residue was heated at elevated temperatures (205 ${ }^{\circ} \mathrm{C}$ ) for $24 \mathrm{~h}$. Vacuum distillation of the obtained mixture and subsequent crystallisation of the crude product resulted in bicyclic imide $\mathbf{6 b}$ in a $42 \%$ yield

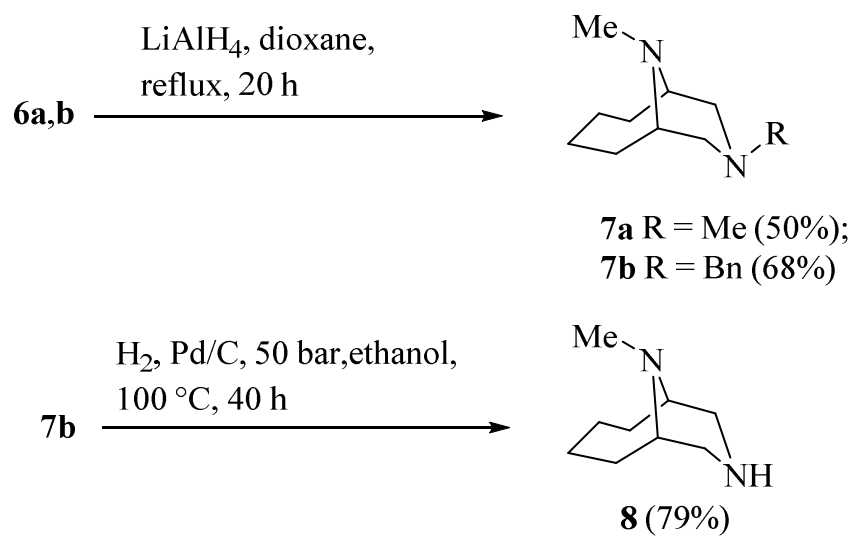

Scheme 2. Synthesis of 8,10-diazabicyclo[4.3.1]decanes.

Finally, the reduction of $\mathbf{6 a}, \mathbf{b}$ with $\mathrm{LiAlH}_{4}$ in dioxane resulted in 8,10-dimethyl- and 8benzyl-10-methyl-8,10-diazabicyclo[4.3.1]decanes $\mathbf{7 a}$ and $\mathbf{7 b}$, respectively (Scheme 2). Hydrogenolysis in ethanol of $\mathbf{7 b}$ gave the target product $\mathbf{8}$. The ${ }^{13} \mathrm{C}$ NMR spectrum of compound 8 contained four signals due to ring carbons at 55.4 (C-1, C-6), 49.6 (C-7, C-9), 32.6 (C-2, C-5) and 26.1 (C-3, C-4) and a signal of the methyl group at $42.5 \mathrm{ppm}$. The freshly distilled 10methyl-8,10-diazabicyclo[4.3.1]decane (8) is a waxy solid that absorbs moisture and carbon dioxide upon exposure to air. 


\section{Conclusions}

In summary, we have developed an efficient five-step method for the synthesis of 10-methyl8,10-diazabicyclo[4.3.1]decane, which is an important scaffold for the preparation of such biologically active compounds, as nicotinic modulators, on a multigram scale starting from commercially available suberic acid.

\section{Experimental Section}

General. All starting materials were purchased from Aldrich or Fluka. Melting points were determined in open capillary tubes on a Büchi B-560 melting point apparatus and are uncorrected. Infrared spectra were recorded with a Bruker Tensor 27 spectrometer using $\mathrm{KBr}$ pellets, $\mathrm{NaCl}$ windows or a single reflection diamond ATR accessory. ATR spectra are not corrected. Raman scattering spectra were recorded with a Bruker FT-RAMII spectrometer. ${ }^{1} \mathrm{H}$ NMR spectra were recorded at $300 \mathrm{MHz}$ on a Varian Inova or at $400 \mathrm{MHz}$ on a Bruker Avance III spectrometer; ${ }^{13} \mathrm{C}$ NMR spectra were registered at $75 \mathrm{MHz}$ or $100 \mathrm{MHz}$, respectively. Chemical shifts, expressed in ppm, were relative to tetramethylsilane (TMS). High-resolution ESI-TOF mass spectra were measured on a Bruker maXis $4 \mathrm{G}$ spectrometer. LC/MS measurements were carried out on a Shimadzu LCMS-2020 system. Vacuum distillation was performed on a Büchi Model B580 GKR oven. Elemental analyses were conducted using a Elemental Analyzer CE-440 (Exeter Analytical, Inc.) by the Microanalytical Laboratory, Department of Organic Chemistry, Kaunas University of Technology.

meso-Dimethyl 2,7-dibromooctanedioate (2). To a round-bottom flask (1000 mL) equipped with a magnetic stirrer, an inert gas inlet and connected to a scrubber, octanedioic acid (440 g, $2.53 \mathrm{~mol})$ and thionyl chloride $(633 \mathrm{~g}, 5.32 \mathrm{~mol})$ were added. The mixture was heated at $40{ }^{\circ} \mathrm{C}$ for $4 \mathrm{~h}$ with stirring until gas evolution was seased. Consequently temperature was raised to 90 ${ }^{\circ} \mathrm{C}$ and bromine (832 g, $5.2 \mathrm{~mol}$ ) was added dropwise to a mixture over a period of $4 \mathrm{~h}$ (while the flask was continuously irradiated with a $200 \mathrm{~W}$ mercury lamp). Finally, absolute methanol (250 $\mathrm{mL}$ ) was added dropwise (vigorous gas evolution!) and a flask was cooled down to rt. The reaction mixture was washed with distilled water $(50 \mathrm{~mL})$, concentrated aqueous sodium acetate $(100 \mathrm{~mL})$ and aqueous sodium sulphite $(100 \mathrm{~mL})$. The separated organic phase was dried in a high vacuum at $90{ }^{\circ} \mathrm{C}$ to yield $864 \mathrm{~g}(95 \%)$ of the crude product, which was distilled at $140{ }^{\circ} \mathrm{C}$ under a vacuum (0.1-0.3 mbar) to yield $764 \mathrm{~g}$ (84\%) of liquid and colourless diester 2 . IR ( $\mathrm{NaCl}$ window, $\left.v_{\max }, \mathrm{cm}^{-1}\right)$ : 3003, 2953, 2862, 1740, 1437, 1357, 1273, 1218, 1196, 1157, 1010. Raman scattering (Stokes shift, $\left.v_{\max }, \mathrm{cm}^{-1}\right): 2955,2862,1740,1440 .{ }^{1} \mathrm{H}$ NMR $\left(400 \mathrm{MHz}, \mathrm{CDCl}_{3}\right): \delta_{\mathrm{H}}$ 1.26-1.52 (m, 4H), 1.90-2.10 (m, 4H), $3.78(\mathrm{~s}, 6 \mathrm{H}), 4.21\left(\mathrm{t}, 2 \mathrm{H}, J\right.$ 7.0 Hz). ${ }^{13} \mathrm{C}$ NMR $(100 \mathrm{MHz}$, $\left.\mathrm{CDCl}_{3}\right): \delta_{\mathrm{C}} 26.4,34.4,45.2,45.3,52.9$, 170.1. Anal. Calcd for $\mathrm{C}_{10} \mathrm{H}_{16} \mathrm{Br}_{2} \mathrm{O}_{4}$ (360.04) : C, 33.36; H, 4.48; Br, 44.39. Found: C, 33.60; H, 4.31; Br, 44.62\%. HRMS (ESI TOF): [M+Na] $]^{+}$, found 
380.9309, 382.9289, 384.9269. $\left[\mathrm{C}_{10} \mathrm{H}_{16}{ }^{79} \mathrm{Br}_{2} \mathrm{O}_{4}+\mathrm{Na}^{+}\right], \quad\left[\mathrm{C}_{10} \mathrm{H}_{16}{ }^{79} \mathrm{Br}^{81} \mathrm{BrO}_{4}+\mathrm{Na}^{+}\right] \quad$ and $\left[\mathrm{C}_{10} \mathrm{H}_{16}{ }^{81} \mathrm{Br}_{2} \mathrm{O}_{4}+\mathrm{Na}^{+}\right]$require $380.9307,382.9287$ and 384.9267 , respectively.

$\left(2 R^{*}, 7 S^{*}\right)$-Dimethyl 1-methylazepane-2,7-dicarboxylate (4) and 8,10-dimethyl-8,10diazabicyclo[4.3.1]decan-7,9-dione (6a). To a glass liner $(250 \mathrm{~mL})$ methylamine $(9.4 \mathrm{~g}, 303$ mmol, dissolved in $100 \mathrm{~mL}$ of dry THF) and compound 2 (36 g, $100 \mathrm{mmol}$, dissolved in $100 \mathrm{~mL}$ of dry THF) were added. The liner was placed in a high pressure stainless steel reactor and the reaction mixture was heated with stirring at $120{ }^{\circ} \mathrm{C}$ for $2 \mathrm{~h}$. Then the reaction mixture was filtered and the solvent was evaporated at reduced pressure. The residue was distilled at $140{ }^{\circ} \mathrm{C}$ under vacuum (0.1-0.3 mbar) to yield $13.0 \mathrm{~g}$ of a crude product, which was purified by column chromatography on silica gel (eluent: hexane-ethyl acetate, 5:1) to yield $6.5 \mathrm{~g}(28 \%)$ of compound 4 as a colourless liquid. IR ( $\mathrm{NaCl}$ window, $\left.v_{\max }, \mathrm{cm}^{-1}\right)$ : 2949, 2864, 1736, 1677, 1437, 1308, 1197, 1170, 1084, 1022. Raman scattering (Stokes shift, $v_{\max }, \mathrm{cm}^{-1}$ ): 2951, 2865, 1728, 1449. ${ }^{1} \mathrm{H}$ NMR $\left(300 \mathrm{MHz}, \mathrm{CDCl}_{3}\right): \delta_{\mathrm{H}} 1.35-1.60(\mathrm{~m}, 4 \mathrm{H}), 1.68-1.84(\mathrm{~m}, 2 \mathrm{H}), 1.88-2.03$ (m, 2H), $2.46(\mathrm{~s}, 3 \mathrm{H}), 3.62(\mathrm{~s}, 6 \mathrm{H}) .{ }^{13} \mathrm{C} \mathrm{NMR}\left(75 \mathrm{MHz}, \mathrm{CDCl}_{3}\right): \delta_{\mathrm{C}} 25.0,30.4,42.7,51.4,64.9$, 174.4. Anal. Calcd for $\mathrm{C}_{11} \mathrm{H}_{19} \mathrm{NO}_{4}$ (229.27): C, 57.62; H, 8.35; N, 6.11. Found: C, 57.78; H, 8.30; N, 6.20\%. HRMS (ESI TOF): $[\mathrm{M}+\mathrm{H}]^{+}$, found 230.1386. $\left[\mathrm{C}_{11} \mathrm{H}_{19} \mathrm{NO}_{4}+\mathrm{H}^{+}\right]$requires 230.1387.

The vacuum distillation residue, obtained after evaporation of azepane $\mathbf{4}$ as described above, was heated in original $100 \mathrm{ml}$ distillation flask with stirring at $200{ }^{\circ} \mathrm{C}$ under argon atmosphere for 6 $\mathrm{h}$. Then the reaction mixture was distilled at $160{ }^{\circ} \mathrm{C}$ under a vacuum $(<0.2 \mathrm{mbar})$ to yield $6.0 \mathrm{~g}$ of a crude product. Product was redistilled in vacuum ( $<0.1 \mathrm{mbar}$ ) at $120{ }^{\circ} \mathrm{C}$ (yield $2.80 \mathrm{~g}$ ) and once again for $5 \mathrm{~h}$ at $80{ }^{\circ} \mathrm{C}$ to afford compound $6 \mathbf{a}$ as a greenish-yellow liquid. Yield $2.0 \mathrm{~g}(10 \%)$. IR $\left(\mathrm{NaCl}\right.$ window, $\left.v_{\max }, \mathrm{cm}^{-1}\right)$ : 2937, 2863, 1727, 1675, 1442, 1355, 1308, 1151, 1061. Raman scattering (Stokes shift, $v_{\max }, \mathrm{cm}^{-1}$ ): 2942, 2865, 1725, 1455, 1290, 1026, 605. ${ }^{1} \mathrm{H}$ NMR (400 $\left.\mathrm{MHz}, \mathrm{CDCl}_{3}\right): \delta_{\mathrm{H}} 1.36-1.48(\mathrm{~m}, 2 \mathrm{H}), 1.63-1.75(\mathrm{~m}, 2 \mathrm{H}), 1.96-2.16(\mathrm{~m}, 4 \mathrm{H}), 2.55(\mathrm{~s}, 3 \mathrm{H}), 3.16(\mathrm{~s}$, $3 \mathrm{H}), 3.63-3.68(\mathrm{~m}, 2 \mathrm{H}) .{ }^{13} \mathrm{C} \mathrm{NMR}\left(100 \mathrm{MHz}, \mathrm{CDCl}_{3}\right): \delta_{\mathrm{C}} 24.4,25.4,32.4,44.8,63.5,174.3$. HRMS (ESI TOF): $[\mathrm{M}+\mathrm{H}]^{+}$, found 197.1283. $\mathrm{C}_{10} \mathrm{H}_{17} \mathrm{~N}_{2} \mathrm{O}_{2}$ requires 197.1285.

Methyl $\left(2 R^{*}, 7 S^{*}\right)$-7-(benzylcarbamoyl)-1-methylazepane-2-carboxylate $(5 \mathrm{~b})$. A roundbottom flask $(25 \mathrm{~mL})$ was equipped with a magnetic stirrer and a Vigreux column. Compound 4 $(1.75 \mathrm{~g}, 7.6 \mathrm{mmol})$, benzyl amine $(0.875 \mathrm{~g}, 8.2 \mathrm{mmol})$ and xylene $(3 \mathrm{~mL})$ were added and the reaction mixture was heated at $120{ }^{\circ} \mathrm{C}$ with stirring over a period of $20 \mathrm{~h}$ under argon. The solvent was evaporated at reduced pressure and then unreacted starting materials were removed under a vacuum $(<0.1 \mathrm{mbar})$ at $100{ }^{\circ} \mathrm{C}$. The residue was crystallized from of ethyl acetate $(3 \mathrm{~mL})$ to yield colourless crystalline azepane $\mathbf{5 b}(0.8 \mathrm{~g})$. After filtration of the product, the filtrate was concentrated and kept at $-18{ }^{\circ} \mathrm{C}$ for $24 \mathrm{~h}$ to give an additional amount of the azepane $\mathbf{5 b}$. The total yield $1.60 \mathrm{~g}(69 \%)$. White solid, mp 82-84 ${ }^{\circ} \mathrm{C}$. IR ( $\left.\mathrm{KBr}, v_{\max }, \mathrm{cm}^{-1}\right): 3269(\mathrm{~N}-\mathrm{H}), 3269$, 3027, 2932, 2878, 2820, 1723 (C=O, ester), 1647 ( $\mathrm{C}=\mathrm{O}$, amide), 1518, 1455, 1360, 1217, 1199, 1146. Raman scattering (Stokes shift $v_{\max }, \mathrm{cm}^{-1}$ ): 3069, 3052, 3036, 2933, 2887, 2821, 1724, $1647,1603,1587,1455,1434,1290,1230,1205,1002 .{ }^{1} \mathrm{H}$ NMR $\left(400 \mathrm{MHz}, \mathrm{DMSO}-d_{6}\right): \delta_{\mathrm{H}}$ 1.36-1.55 (m, 2H, 3- $\left.\mathrm{CH}_{2}\right), 1.42-1.49\left(\mathrm{~m}, 2 \mathrm{H}, 4-\mathrm{CH}_{2}\right), 1.72-1.92\left(\mathrm{~m}, 2 \mathrm{H}, 2-\mathrm{CH}_{2}\right), 1.87-1.97(\mathrm{~m}$, 
2H, 6- $\left.\mathrm{CH}_{2}\right), 2.41\left(\mathrm{~s}, 3 \mathrm{H}, \mathrm{NCH}_{3}\right), 3.32(\mathrm{dd}, J$ 7.5, $5.0 \mathrm{~Hz}, 2-\mathrm{H}), 3.56\left(\mathrm{~s}, 3 \mathrm{H}, \mathrm{OCH}_{3}\right), 3.69$ (dd, $J$ 7.6, 4.7 Hz, 7-H), 4.26-4.37 (m, 2H, $\mathrm{CH}_{2}$-benzyl), 7.20-7.39 (m, 5H, ArH), 8.45 (br s, 1H, NH). HRMS (ESI TOF): $[\mathrm{M}+\mathrm{H}]^{+}$, found 305.1864. $\left[\mathrm{C}_{17} \mathrm{H}_{24} \mathrm{~N}_{2} \mathrm{O}_{3}+\mathrm{H}^{+}\right]$requires 305.1860.

8-Benzyl-10-methyl-8,10-diazabicyclo[4.3.1] decan-7,9-dione (6b). A round-bottom flask (500 $\mathrm{mL}$ ) was equipped with a magnetic stirrer and a Vigreux column (with a mounted Claisen adapter, a side-on Liebig condenser and a top inert gas inlet). Compound 4 (158.6 g, $692 \mathrm{mmol}$ ), benzyl amine $(78 \mathrm{~g}, 729 \mathrm{mmol})$ and xylene $(150 \mathrm{~mL})$ were added and the reaction mixture was heated at $160{ }^{\circ} \mathrm{C}$ (oil bath temperature) with stirring over a period of $72 \mathrm{~h}$ under argon. Formed methanol was removed by continual rectification. The solvent (xylene) was evaporated at reduced pressure and then unreacted starting materials were removed under vacuum (0.1-0.3 mbar) at $120{ }^{\circ} \mathrm{C}$. The residue was heated at $205{ }^{\circ} \mathrm{C}$ for $24 \mathrm{~h}$ under argon. Finally, the mixture was distilled at $180{ }^{\circ} \mathrm{C}$ under a vacuum (0.1-0.3 mbar). The collected condensate was crystallized from ethyl acetate $(20 \mathrm{~mL})$ to yield dione $\mathbf{6 b}(55.0 \mathrm{~g})$. After filtration of the product, the filtrate was kept at $-18{ }^{\circ} \mathrm{C}$ for $24 \mathrm{~h}$ to give an additional amount of the dione $\mathbf{6 b}$. The total yield $79.2 \mathrm{~g}(42 \%)$. Colourless crystals, mp 68-69 ${ }^{\circ} \mathrm{C}$. IR (KBr, $\left.v_{\max }, \mathrm{cm}^{-1}\right): 2944,1722,1670$, 1457, 1435, 1340, 1191, 742, 704. Raman scattering (Stokes shift, $v_{\max }, \mathrm{cm}^{-1}$ ): 3055, 3040, 2946, 1721, 1452, 1435, 1002. ${ }^{1} \mathrm{H}$ NMR (300 MHz, $\left.\mathrm{CDCl}_{3}\right): \delta_{\mathrm{H}} 1.30-1.46(\mathrm{~m}, 3 \mathrm{H}), 1.58-1.74(\mathrm{~m}, 2 \mathrm{H})$, 1.92-2.16 (m, 2H), 2.53 (s, 3H); $3.66(\mathrm{dd}, 2 \mathrm{H}, J$ 7.0, $3.7 \mathrm{~Hz}), 4.98$ (s, 2H), 7.18-7.40 (m, 5H). ${ }^{13} \mathrm{C}$ NMR $\left(75 \mathrm{MHz}, \mathrm{CDCl}_{3}\right): \delta_{\mathrm{C}} 24.3,32.4,42.1,44.9,63.6,127.3,128.3,128.7,136.9,173.8$. Anal. Calcd for $\mathrm{C}_{16} \mathrm{H}_{20} \mathrm{~N}_{2} \mathrm{O}_{2}$ (272.34): C, 70.56; H, 7.40; N, 10.29. Found: C, 70.48; H, 7.30; N, 10.44\%. HRMS (ESI TOF): $[\mathrm{M}+\mathrm{H}]^{+}$, found 273.1599. $\left[\mathrm{C}_{16} \mathrm{H}_{20} \mathrm{~N}_{2} \mathrm{O}_{2}+\mathrm{H}^{+}\right]$requires 273.1598 .

8,10-Dimethyl-8,10-diazabicyclo[4.3.1]decane (7a). To a round-bottom flask (50 mL) equipped with a magnetic stirrer, an Allihn condenser and an argon adapter, compound 6a (2.8 g, 14.2 mmol), absolute dioxane $(15 \mathrm{~mL})$ and $\mathrm{LiAlH}_{4}$ (pellets, $1.0 \mathrm{~g}, 26.3 \mathrm{mmol}$ ) were placed and the mixture was stirred in an oil bath at $120{ }^{\circ} \mathrm{C}$ for $20 \mathrm{~h}$ under argon atmosphere. The reaction mixture was cooled down and a mixture of water $(1 \mathrm{~mL})$ and dioxane $(2 \mathrm{~mL})$ was added dropwise under vigorous stirring. After $1 \mathrm{~h}$ to the mixture an aqueous $\mathrm{NaOH}$ solution (30\%, 4 $\mathrm{mL}$ ) was added. The formed inorganic solids were filtered off, the organic phase was separated and evaporated under reduced pressure. The resulting liquid was purified by distillation under a vacuum (0.1-0.2 mbar) at $60{ }^{\circ} \mathrm{C}$ to afford the target product 7a, as a colourless liquid. Yield $1.2 \mathrm{~g}$ (50\%). IR (ATR, $v_{\max }, \mathrm{cm}^{-1}$ ): 2923, 2851, 2784, 1676, 1461, 1442, 1279, 1168, 1065. Raman scattering (Stokes shift, $v_{\max }, \mathrm{cm}^{-1}$ ): 2933, 2887, 2821, 1724, 1605, 1587, 1458, 1434, 1290. ${ }^{1} \mathrm{H}$ NMR (400 MHz, CDCl $\left.{ }_{3}\right): \delta_{\mathrm{H}} 1.54-1.68(\mathrm{~m}, 4 \mathrm{H}), 1.82-2.04(\mathrm{~m}, 4 \mathrm{H}), 2.15(\mathrm{~s}, 3 \mathrm{H}), 2.20(\mathrm{dd}, 2 \mathrm{H}, J$ 10.8, $4.3 \mathrm{~Hz}), 2.43$ (d, 2H, J $10.9 \mathrm{~Hz}), 2.59$ (s, 3H), 2.90-2.95 (m, 2H). ${ }^{13} \mathrm{C}$ NMR (100 MHz, $\mathrm{CDCl}_{3}$ ): $\delta_{\mathrm{C}} 26.2$, 33.4, 42.1, 47.0, 56.6, 59.6. HRMS (ESI TOF): $[\mathrm{M}+\mathrm{H}]^{+}$, found 169.1697. $\left[\mathrm{C}_{10} \mathrm{H}_{20} \mathrm{~N}_{2}+\mathrm{H}^{+}\right]$requires 169.1699 .

8-Benzyl-10-methyl-8,10-diazabicyclo[4.3.1]decane (7b). To a round-bottom flask $(500 \mathrm{~mL})$ equipped with a magnetic stirrer, an Allihn condenser and an argon adapter, compound $\mathbf{6 b}$ (31.3 $\mathrm{g}, 115 \mathrm{mmol})$, absolute dioxane $(250 \mathrm{~mL})$ and $\mathrm{LiAlH}_{4}$ (pellets, $5.6 \mathrm{~g}, 147 \mathrm{mmol}$ ) were placed and the mixture was stirred at $120{ }^{\circ} \mathrm{C}$ for $20 \mathrm{~h}$ under argon atmosphere. The reaction mixture was 
cooled down and a mixture of water $(6 \mathrm{~mL})$ and dioxane $(10 \mathrm{~mL})$ was added dropwise under vigorous stirring. After $1 \mathrm{~h}$ an aqueous $\mathrm{NaOH}$ solution $(30 \%, 30 \mathrm{~mL})$ was added. The formed inorganic solids were filtered off, the organic phase was separated and evaporated under reduced pressure. The residue was purified by distillation under a vacuum (0.1-0.2 mbar) at $125{ }^{\circ} \mathrm{C}$ to afford the target product $\mathbf{7 b}$, as a colourless liquid. Yield $19.1 \mathrm{~g}(68 \%)$. IR ( $\mathrm{NaCl}$ window, $v_{\max }$, $\mathrm{cm}^{-1}$ ): 2915, 2799, 1674, 1453, 1239, 1174, 1062, 731, 698. Raman scattering (Stokes shift, $v_{\max }$, $\left.\mathrm{cm}^{-1}\right): 3056,2912,2809,1604,1448,1004 .{ }^{1} \mathrm{H}$ NMR $\left(300 \mathrm{MHz}, \mathrm{CDCl}_{3}\right): \delta_{\mathrm{H}} 1.55-1.75(\mathrm{~m}, 4 \mathrm{H})$, 1.92-2.08 (m, 4H), 2.30 (dd, 2H, J 11.3, $4.0 \mathrm{~Hz}$ ), 2.50 (d, 2H, J $10.6 \mathrm{~Hz}$ ), 2.62 (s, 3H), 2.90$2.98(\mathrm{~m}, 2 \mathrm{H}), 3.40(\mathrm{~s}, 2 \mathrm{H}), 7.20-7.38(\mathrm{~m}, 5 \mathrm{H}) .{ }^{13} \mathrm{C} \mathrm{NMR}\left(75 \mathrm{MHz}, \mathrm{CDCl}_{3}\right): \delta_{\mathrm{C}} 26.2,33.4,42.1$, 56.7, 57.5, 63.8, 126.8, 128.1, 128.9, 138.9. Anal. Calcd for $\mathrm{C}_{16} \mathrm{H}_{24} \mathrm{~N}_{2}$ (244.38): C, 78.64; $\mathrm{H}$, 9.90; N, 11.46. Found: C, 78.36; H, 9.82; N, 11.58\%. HRMS (ESI TOF): $[\mathrm{M}+\mathrm{H}]^{+}$, found 245.2012. $\left[\mathrm{C}_{16} \mathrm{H}_{24} \mathrm{~N}_{2}+\mathrm{H}^{+}\right]$requires 245.2012.

10-Methyl-8,10-diazabicyclo[4.3.1]decane (8). To a glass liner (300 mL) under an argon atmosphere absolute ethanol $(80 \mathrm{~mL})$, compound $7 \mathbf{b}(19.0 \mathrm{~g}, 77 \mathrm{mmol})$ and $10 \%$ palladium on charcoal $(0.8 \mathrm{~g})$ were added. The hydrogenation was carried out in a high pressure stainless steel reactor by stirring the mixture at $100{ }^{\circ} \mathrm{C}$ under hydrogen atmosphere (50 bar) for $40 \mathrm{~h}$. After cooling down and decompression, the reaction mixture was filtered off, the solvent evaporated at reduced pressure and the resulting liquid was distilled at $70{ }^{\circ} \mathrm{C}$ under a vacuum (0.1-0.2 mbar) to afford the target compound 8 as a waxy solid. Yield $9.5 \mathrm{~g}(79 \%) .{ }^{1} \mathrm{H}$ NMR $\left(300 \mathrm{MHz}, \mathrm{CDCl}_{3}\right)$ : $\delta_{\mathrm{H}} 1.45-1.75(\mathrm{~m}, 6 \mathrm{H}), 1.87-2.00(\mathrm{~m}, 2 \mathrm{H}), 2.16(\mathrm{~s}, 1 \mathrm{H}), 2.49(\mathrm{~s}, 3 \mathrm{H}), 2.51(\mathrm{~d}, 2 \mathrm{H}, J 12.4 \mathrm{~Hz})$, $2.65(\mathrm{~m}, 2 \mathrm{H}), 2.95(\mathrm{dd}, 2 \mathrm{H}, J$ 12.1, $4.0 \mathrm{~Hz}) .{ }^{13} \mathrm{C} \mathrm{NMR}\left(75 \mathrm{MHz}, \mathrm{CDCl}_{3}\right): \delta_{\mathrm{C}} 26.1,32.6,42.5$, 49.6, 55.4. Anal. Calcd for $\mathrm{C}_{9} \mathrm{H}_{18} \mathrm{~N}_{2}$ (154.25): C, 70.08; H, 11.76; N, 18.16. Found: C, 70.28; H, 11.74; N, 18.02\%. HRMS (ESI TOF): $[\mathrm{M}+\mathrm{H}]^{+}$, found 155.1543. $\left[\mathrm{C}_{9} \mathrm{H}_{18} \mathrm{~N}_{2}+\mathrm{H}^{+}\right]$requires 155.1543 .

\section{References}

1. O'Donnell, J. C.; Peng, L.; O'Neill, B. T.; Arnold, E. P.; Mather, R. J.; Sands, S. B.;

Shrikhande, A.; Lebel, L. A.; Spracklin, D. K.; Nedza, F. M. Bioorg. Med. Chem. Lett. 2009, 19, 4747-4751.

http://dx.doi.org/10.1016/j.bmcl.2009.06.059

PMid:19576766

2. Biton, B.; Bergis, O. E.; Galli, F.; Nedelec, A.; Lochead, A. W.; Jegham, S.; Godet, D.; Lanneau, C.; Santamaria, R.; Chesney, F.; Léonardon, J.; Granger, P.; Debono, M. W.; Bohme, G. A.; Sgard, F.; Besnard, F.; Graham, D.; Coste, A.; Oblin, A.; Curet, O.; Vigé, X.; Voltz, C.; Rouquier, L.; Souilhac, J.; Santucci, V.; Gueudet, C.; Françon, D.; Steinberg, R.; Griebel, G.; Oury-Donat, F.; George, P.; Avenet, P.; Scatton, B. Neuropsychopharmacol. 2007, 32, 1-16. 
http://dx.doi.org/10.1038/sj.npp.1301189

PMid:17019409

3. Peters, D.; Timmermann, D. B.; Olsen, G. M.; Nielsen, E. Ø.; Jørgensen, T. D. U.S. Patent 7 612074 B2, 2009.

4. Audouze, K.; Nielsen, E. Ø.; Olsen, G. M.; Ahring, P.; Jørgensen, T. D.; Peters, D.; Liljefors, T.; Balle, T. J. Med. Chem. 2006, 49, 3159-3171.

http://dx.doi.org/10.1021/jm058058h

PMid:16722635

5. Galli, F.; Leclerc, O.; Lochead, A. U.S. Patent 6844337 B2, 2005.

6. Barlocco D.; Cignarella G.; Tondi D.; Vianello P.; Villa S.; Bartolini A.; Ghelardini C.;

Galeotti N.; Anderson D. J.; Kuntzweiler T. A.; Colombo D.; Toma L. J. Med. Chem. 1998, 41, 674-681.

http://dx.doi.org/10.1021/jm970427p

PMid:9513595

7. McGuirk, P. R.; Jefson, M. R.; Mann, D. D.; Elliot, N. C.; Chang, P.; Cisek, E. P.; Cornell, C. P.; Gootz, T. D.; Haskell, S. L.; Hindhahl, M. S.; LaFleur, L. J.; Rosenfeld, M. J.; Shryock, T. R.; Silvia, A. M.; Weber, F. H. J. Med. Chem. 1992, 35, 611-620. http://dx.doi.org/10.1021/jm00082a001

8. Deuther-Conrad, W.; Fisher, S.; Hiller, A.; Becker, G.; Cumming, P.; Xiong, G.; Funke, U.; Sabri, O.; Peters, D.; Brust, P. Eur. J. Nucl. Mol. Imaging 2011, 38, 1541-1549.

http://dx.doi.org/10.1007/s00259-011-1808-y

PMid:21484373

9. Brust, P.; Peters, D.; Deuther-Conrad, W. Curr. Drug Targets 2012, 13, 594-601. PMid:22300025

10. Audrain, H.; Bender, D.; Scheel-Krüger, J.; Nielsen, E. Ø.; Olsen, G. M.; Peters, D.; Cumming, P. J. Labelled Compd. Radiopharm. 2003, 46, 873-882.

http://dx.doi.org/10.1002/jlcr.726

11. Peters, D; Olsen, G. M.; Nielsen, E. O.; Timmermann, D. B.; Loechel, S. C.; Christensen, J. K.; Dyhring, T. WO 2007135121, 2007.

12. Rubstov, M. V.; Mikhlina, E. E.; Vorobéva, V. Ya.; Yanina, A. D. Zh. Obshch. Khim. 1964, 34, 2222-2226.

13. Vervisch, K.; D'hooghe, M.; Törnroos, K. W.; De Kimpe, N. J. Org. Chem. 2010, 75, 77347744.

http://dx.doi.org/10.1021/jo101646u

PMid:20977252

14. Cignarella, G.; Nathansohn, G.; Occelli, E. J. Org. Chem. 1961, 26, 2747-2755. http://dx.doi.org/10.1021/jo01066a031

15. Paliulis, O.; Peters, D.; Miknius, L.; Šačkus, A. Org. Prep. Proced. Int. 2007, 39, 86-89. http://dx.doi.org/10.1080/00304940709458585 
16. Blackman, S. W.; Baltzly, R. J. Org. Chem. 1961, 26, 2750-2755. http://dx.doi.org/10.1021/jo01066a032

17. Huang, L. J.; Teng, D. W. Chin. Chem. Lett. 2011, 22, 523-526. http://dx.doi.org/10.1016/j.cclet.2010.11.030

18. Goss, F. R.; Ingold, C. K. J. Chem. Soc. 1926, 1471-1477, and references cited therein. http://dx.doi.org/10.1039/jr9262901471

19. Satoh, S.; Itoh, M.; Suginome, H.; Tokuda, M. Bulletin of the Faculty Engineering, Hokkaido Univ. 1981, No. 102, 33-42.

20. Zhang, W.; Liang, Q.; Li, H.; Meng, X.; Li, Z. Tetrahedron 2013, 69, 664-672. http://dx.doi.org/10.1016/j.tet.2012.11.004

21. Johnson, T. A.; Sohn, J.; Vaske, Y. M.; White, K. N.; Cohen, T. L.; Vervoort, H. C.; Tenney, K.; Valeriote, F. A.; Bjeldanes, L. F.; Crews, P. Bioorg. Med. Chem. 2012, 20, 4348-4355. http://dx.doi.org/10.1016/j.bmc.2012.05.043

PMid:22705020 PMCid:PMC3417756

22. Hoffman, H.; Haag-Richter, S.; Kurz, M.; Tietgen, H. U.S. Patent 7153 846, 2004.

23. Kulanthaivel, P.; Hallock, Y. F.; Boros, C.; Hamilton, S. M.; Janzen, W. P.; Ballas, L. M.; Loomis, C. R.; Jiang, J. B.; Katz, B.; Steiner, J. R.; Clardy, J. J. Am. Chem. Soc. 1993, 115, 6452-6453.

http://dx.doi.org/10.1021/ja00067a087

24. Gilmet, J.; Sullivan, B.; Hudlicky, T. Tetrahedron 2009, 65, 212-220. http://dx.doi.org/10.1016/j.tet.2008.10.070

25. Nú-ez-Villanueva, D.; Infantes, L.; García-López, M. T.; González-Mu-iz, R.; MartínMartínez, M. J. Org. Chem. 2012, 77, 9833-9839.

26. Cini, E.; Bifulco, G.; Menchi, G.; Rodriquez, M.; Taddei, M. Eur. J. Org. Chem. 2012, 77, 2133-2141.

http://dx.doi.org/10.1002/ejoc.201101387

27. Braun, S.; Kalinowski, H.-O.; Berger, S. 150 and More Basic NMR Experiments; WileyVCH: Weinheim, 1998, p 596. 